\title{
OUTER CAR BODY PANELS MADE OF DUAL-PHASE STEEL
}

\author{
Michal VALEŠ, Vít NOVÁK, František TATÍČEK, Jan ŠANOVEC, Lukáš CHRÁŠŤANSKÝ \\ CTU - Czech Technical University in Prague, Prague, Czech Republic, EU, michal.vales@fs.cvut.cz
}

https://doi.org/10.37904/metal.2019.824

\begin{abstract}
Due to stricter emissions standards of carbon dioxide production, automobile manufacturers are forced to search innovative solutions. An eventuality to reduce emission production is to reduce the weight of a car body. This weight reduction can be achieved by replacing material used in production of outer car body parts. The subject of this article is use of dual phase steel with tensile strength higher than $500 \mathrm{MPa}$ for outer car body parts. Stampings used in experiment come from current models of ŠKODA AUTO, a.s. Due to lack of experience, material cards and feasibility of these parts were evaluated. Attention was paid primarily on crack initiation, wrinkling and springback.
\end{abstract}

Keywords: Sheet Metal Forming, High Strength Steel, Outer Car Body Parts, Dual-Phase Steel, Springback

\section{INTRODUCTION}

Automotive industry requires parts with as high utility value as possible to meet customer demands in a very competitive market. Parts must meet quality standards and be made within the shortest time and lowest cost. These days, the key problem is to fulfill emission limits set by European Parliament and Council. The allowable production of CO2 will be $95 \mathrm{~g} / \mathrm{km}$ by year 2020. In consequence, a new type of drive must be developed, or car weight must be reduced. Consumption of $4.1 \mathrm{l} / 100 \mathrm{~km}$ of gasoline or $3.5 \mathrm{l} / 100 \mathrm{~km}$ of oil corresponds to this limit [1].

Car weight reduction can be achieved with improvement of car body. Application of materials with high strength results in smaller volumes and lower thickness thus in lower weight. The other way is to use materials with better strength to density ratio, e.g. aluminium or plastics. The most effective but also expensive way is to use composites or sandwich materials. Steel is still a very perspective material and its mechanical and chemical properties vastly varies according to chemical composition, heat treatment and its manufacturing. The benefits of steel are satisfactory price, recyclability and low carbon footprint. The partial solution to mentioned topic is an application of High Strength Steel (HSS) or Advanced High Strength Steel (AHSS) in production of outer car body parts. Replacement of currently used mild steels with these materials can reduce weight of selected parts by up to $20 \%$. The problem is that HSS materials are characterized with lower ductility and formability than mild steels. This causes a problem in context of demanding design of current cars [2-4].

Outer car body parts can be characterized with demanding dimension accuracy and esthetic criterions, as customers perceive them. Springback is an important problem in stamping. During springback compensation, surface of stamping tools must be adjusted from two to five times, which leads to increment of financial cost. These costs can be reduced thanks to higher fidelity of numerical simulation, especially for HSS materials $[5,6]$.

\section{DUAL-PHASE STEEL CR290Y490T-DP (DP500)}

CR290Y490T-DP (generally called DP500) steel is a part of dual-phase steel family. The structure consists of ductile fine-grained ferritic matrix and hard martensitic phase dispersed in the form of islands. It is a low carbon steel with a $10-40 \%$ share of martensite. This combination allows a good combination of hardness, ductility and weldability. DP500 is thanks to high absorption capacity and fatigue strength commonly used for structural parts of BIW. Another benefit is presence of $\mathrm{BH}$ effect. Due to complexity of sheet metal forming stress states, 
formability cannot be stated by a single index and results from mechanical properties. Equivalent of DP500 is HCT500X (according to ČSN EN 10027). Selected mechanical properties of steel DP500, steel HX180BD and steel DC05 are stated in Table 1. $[7,8]$

Table 1 Mechanical properties of selected steel grades

\begin{tabular}{|c|c|c|c|c|c|}
\hline $\begin{array}{c}\text { Steel Grade (ČSN } \\
\text { EN 10027-1) }\end{array}$ & $\begin{array}{c}\text { Yield Strength } \\
(\mathbf{M P a})\end{array}$ & $\begin{array}{c}\text { Tensile Strength } \\
(\mathbf{M P a})\end{array}$ & $\begin{array}{c}\text { Ductility } \\
(\%)\end{array}$ & $\begin{array}{c}\text { Strain } \\
\text { hardening } \\
\text { exponent } \\
(-)\end{array}$ & $\begin{array}{c}\text { Plastic strain } \\
\text { ratio } \\
(-)\end{array}$ \\
\hline- & $R_{\mathrm{p} 0,2}$ & $R_{\mathrm{m}}$ & $A_{80 \mathrm{~mm}}$ & $n$ & $r_{(\mathrm{m} / 20)}$ \\
\hline DC05 & $140-180$ & $260-330$ & $\geq 39$ & $\geq 0.20$ & $\geq 1.6$ \\
\hline HX180BD & $180-240$ & $290-370$ & $\geq 34$ & $\geq 0.17$ & $\geq 1.3$ \\
\hline HCT500X & $290-380$ & $490-600$ & $\geq 24$ & $\geq 0.15$ & - \\
\hline
\end{tabular}

\section{EXPERIMENT SET-UP}

Application of HSS in production of outer car body parts is complicated by demanding design of currently produced cars and by lack of knowledge with HSS materials in production of these parts.

The goal of this article is to validate three independent material cards of steel DP500. These material cards comprise mechanical properties, hardening curve, yield locus and FLC (Forming Limit Curve). To validate these cards, selected parts were virtually stamped in software AutoForm R7 and results were compared to reality. Evaluation was based on crack presence, wrinkling, thinning and springback. The overview of used material cards is in Table 2.

Table 2 Overview of used material cards (MTC x)

\begin{tabular}{|c|c|c|c|c|c|}
\hline Material Card & $\begin{array}{c}\text { Yield Strength } \\
\text { (MPa) }\end{array}$ & $\begin{array}{c}\text { Tensile } \\
\text { Strength } \\
(\mathrm{MPa})\end{array}$ & $\begin{array}{c}\text { Ductility } \\
(\%)\end{array}$ & $\begin{array}{c}\text { Strain } \\
\text { hardening } \\
\text { exponent } \\
(-)\end{array}$ & $\begin{array}{c}\text { Plastic strain } \\
\text { ratio } \\
(-)\end{array}$ \\
\hline & $R_{\mathrm{p} 0,2}$ & $R_{\mathrm{m}}$ & $A_{80 \mathrm{~mm}}$ & $n$ & $r_{(\mathrm{m} / 20)}$ \\
\hline MTC 1 & 336.9 & 526.6 & 16.2 & 0.146 & 0.99 \\
\hline MTC 2 & 320.8 & 511.8 & 17.7 & 0.171 & 0.96 \\
\hline MTC 3 & 335.0 & 552.2 & 17.7 & 0.166 & 1.03 \\
\hline
\end{tabular}

Stamping tests were produced on a serial press at a production rate. The fact, that the tool has been tried-out into a material with larger thickness, may affect the formation of wrinkling or other auditory problems on the stamping. Attention was paid primarily on crack initiation, wrinkling and springback. Tested parts were "side door outer rear" (shown in Figure 1) and "fifth door outer lower" (shown in Figure 10). Overview of materials used in serial production and its thickness is shown in Table 3.

Table 3 Overview of tested stampings (materials and thickness)

\begin{tabular}{|c|c|c|c|c|}
\hline \multirow{2}{*}{ Car Model } & \multicolumn{2}{|c|}{ Outer Car Body Part } & Material & $\begin{array}{c}\text { Thickness } \\
(\mathbf{m m})\end{array}$ \\
\hline \multirow{2}{*}{ FABIA III } & \multirow{2}{*}{ Door Rear Outer } & Serie & HX180BD & 0.65 \\
\cline { 2 - 4 } & Test & DP500 & 0.60 \\
\hline \multirow{2}{*}{ RAPID SPACEBACK } & $\begin{array}{c}\text { Fifth Door Outer } \\
\text { Lower }\end{array}$ & Serie & HX180BD & 0.70 \\
\cline { 2 - 4 } & Test & DP500 & 0.60 \\
\hline
\end{tabular}




\section{EXPERIMENT}

\subsection{FABIA III}

The first analyzed part is the "side door outer rear", which comes from current model the ŠKODA FABIA (since 2014). The mentioned part is shown in Figure 1. The numerical simulation used in the experiment is based on milling data (NCM) considering casting and milling. These data were also modified based on scan of real tools. The FEM network is oriented along the bend edge in OP.50 (calibration, bending of hemming flanges). The shape of the tools used for the calculation is shown in Figure 2.
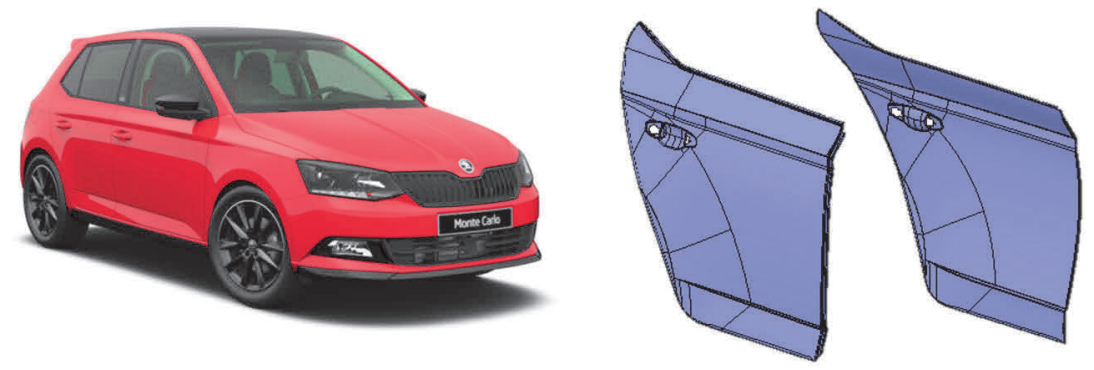

Figure 1 ŠKODA FABIA III (2014), side door outer rear

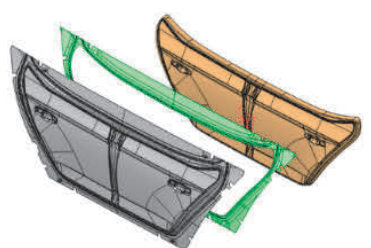

OP.20 - deep drawing

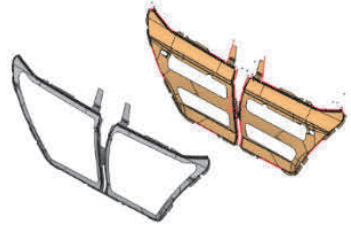

OP.30 - trimming

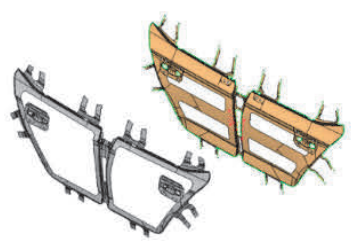

OP.40 - trimming, piercing

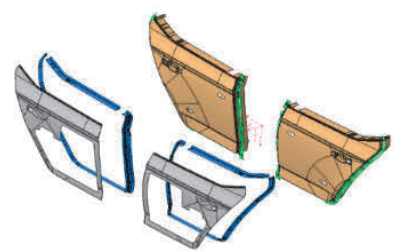

OP.50 - calibration, bending of hem-flanges

Figure 2 ŠKODA FABIA, CAD data of tools

The reference simulation, which is used to verify the fidelity of the numerical simulation setting, relates to steel HX180BD. Simulation with DP500 takes into account the fact that the tool has been tried-out into different material thickness. The numerical simulation is calculated with all three DP500 material models. The "Formability" parameter in OP.20 (deep drawing) is shown in Figure 3. The figure shows that the numerical simulation correctly identifies the occurrence of cracks in technological surfaces between the right and left doors.
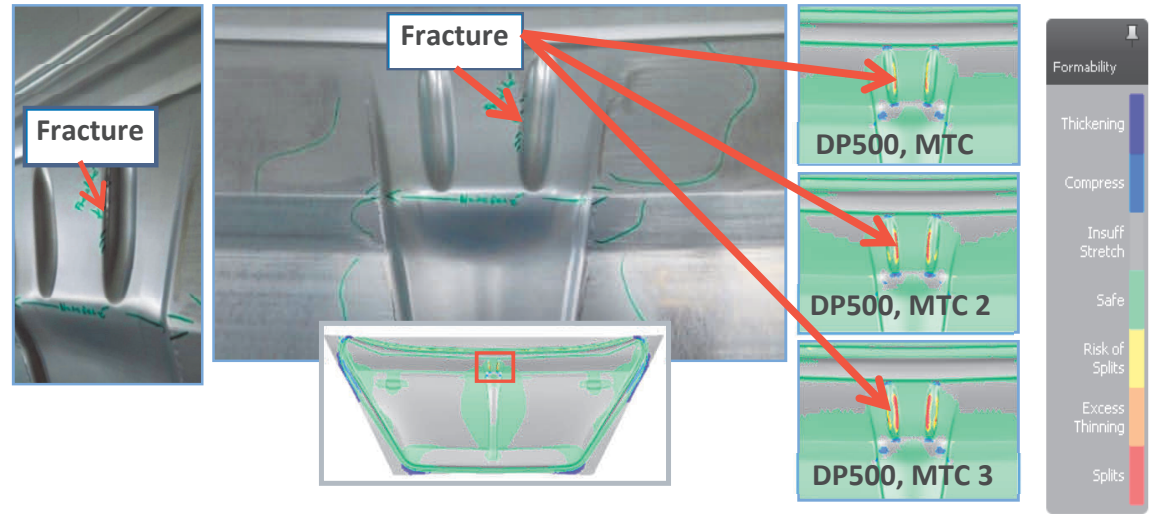

Figure 3 "Formability" after OP.20 (Deep Drawing) 
Springback analysis was performed with respect to the real measurement process. The position of the RPS points (points in which the stamping part is clamped) together with the order of clamping was identical to real measurement. Figure 4 and Figure 5 shows the result of the real springback analysis. Figures 6-8 represent results for each material card of DP500. In all three cases, the springback trend in area A matched. Stamping has the highest degree of springback in the direction inside the car. In area B (the largest springback in direction outside the car), the springback trend is best predicted by the material card 1, while the springback value and trend in this case is also closest to the real measurement. The highest difference between real measurement and numerical simulation occurs in area $\mathrm{C}$, where springback in real measurements does not show such a high value. In terms of the trend of springback development, it can be said that the material card 1 best corresponds to the result of physical scanning. Material cards 1 gives also best results in thinning.

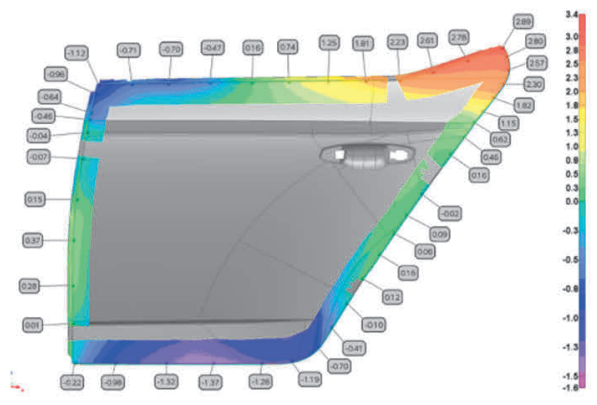

Figure 4 Springback measurement result, HX180BD

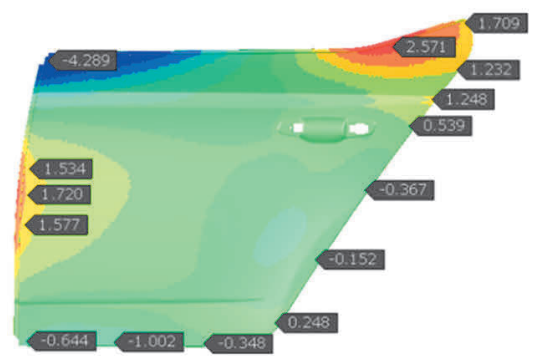

Figure 6 Springback in normal direction, DP500, MTC 1

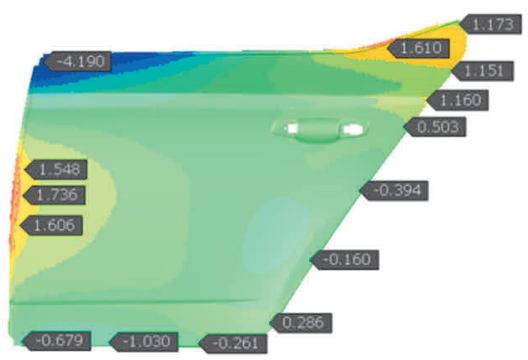

Figure 7 Springback in normal direction, DP500, MTC 2

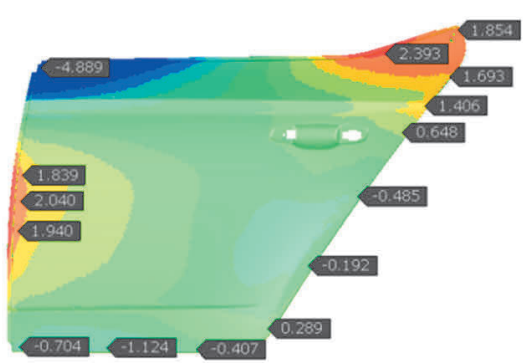

Figure 8 Springback in normal direction, DP500, MTC 3

\subsection{RAPID SPACEBACK}

The second analyzed part is the "fifth door outer lower", which is stamped for the current ŠKODA RAPID SPACEBACK (since 2013). This part is shown in Figure 9. The numerical simulation procedure is the same as in the Fabia III project. The geometry of the press tools is shown in Figure 10.
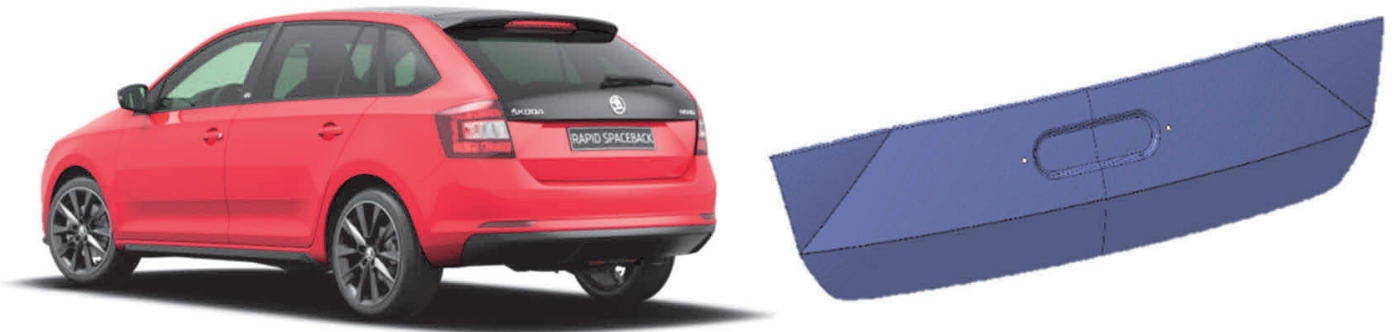

Figure 9 ŠKODA RAPID SPACEBACK (2012), fifth door outer rear 


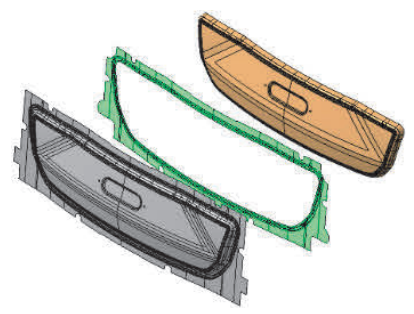

OP.20 - deep drawing

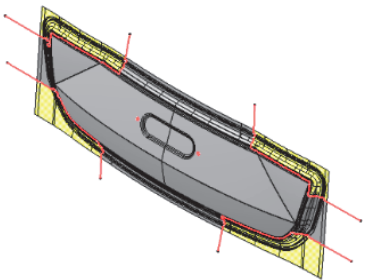

OP.30 - trimming

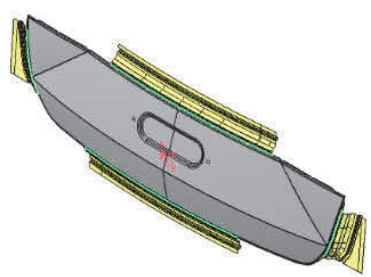

OP.40 - trimming, piercing

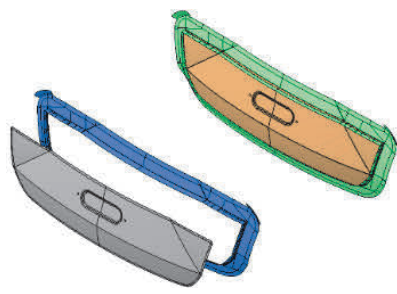

OP.50 - calibration, bending of hem-flanges

Figure 10 ŠKODA RAPID SPACEBACK, CAD data of tools

Based on the results obtained during the evaluation of the ŠKODA FABIA side door outer rear, only the material card 1 was used for the simulation. The aim of this part of the experiment is to evaluate the accuracy of springback for the selected part. The AutoForm R7 software was used again for the calculation. The surface of the real stamping was scanned using a CMS 106 laser scanner from HEXAGON.

The correspondence of the numerical simulation and the physical stamping can be evaluated using the springback trend. The areas of maximum and minimum springback values are identical for both physical and virtual analysis results. The only difference is the size of the area of the extremes and the value of the springback, especially for the positive values of the springback (in direction outside the car).

However, the uncertainty of virtual springback prediction is similar for both monitored materials. It can be argued that the accuracy of the springback prediction for DP500 does not differ significantly from the standard material DC05. Springback compensation in the pre-production phase is therefore possible for both tested materials and this criterion is not an obstacle to the applicability of the DP500 steel. Results of springback analysis are shown in Figure 11.
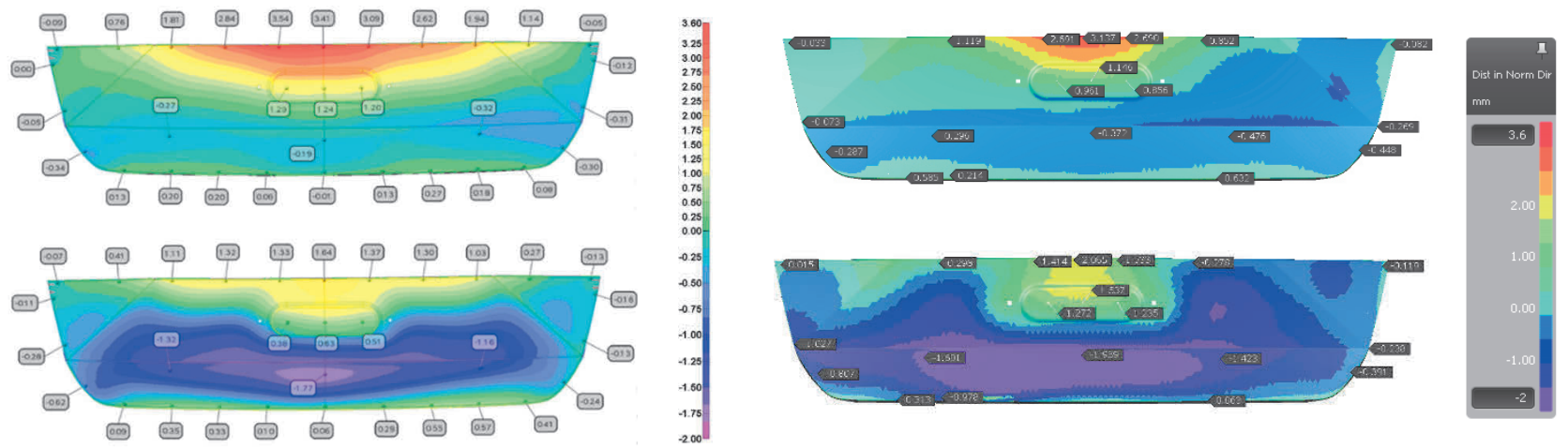

Figure 11 Left: Virtual springback in normal direction, DC05 (above) and DP500 - MTC 1 (below); right: Virtual springback in normal direction, DC05 (above) and DP500 - MTC 1 (below)

\section{CONCLUSION}

This article deals with the production of outer car body parts using high-strength steel DP500. Absence of literature and publications dealing with specific use of these steels implies an innovative approach and methodology for their processing. Tests with dual-phase steel DP500 have proved its potential applicability. The dimensionality and quality of the part can be evaluated as sufficient. The material card 1 was selected as best for further feasibility studies and process simulations. The material card 2 will be further validated. Before 
the serial production of parts made of DP500, it is necessary to also carry out the following tests: flanging test, painting test, corrosion test etc.

The main objective is to propose a complex methodology for the use of high strength steels for manufacturing of outer car body parts. Another goal is to use modern tools in numerical simulation for its higher fidelity. In addition, the increased precision of numerical simulation will lead to time and cost savings in tool try-out. The robustness of the proposed process is also an indispensable aspect of the methodology. It should be noted that the deployment of DP500 is strongly conditioned by the appropriate part geometry [9-12].

\section{ACKNOWLEDGEMENTS}

\section{The research was financed by SGS19/163/OHK2/3T/12. Research, optimization and innovation of production processes.}

\section{REFERENCES}

[1] NAŘíZENÍ EVROPSKÉHO PARLAMENTU A RADY (ES) Č. 443/2009. Praha: Úřední věstník Evropské unie, 2009.

[2] VALEŠ, M., CHRÁŠŤANSKÝ, L., TATÍČEK, F. Comparison of Numerical Simulation and Deep Drawing Test of DP500 Steel. In: METAL 2018 Conference Proceedings. METAL 2018 - 27th International Conference on Metallurgy and Materials. Ostrava: TANGER, 2018, pp.501-506.

[3] EVIN, E. The Deformation Properties of High Strength Steel Sheets for Auto-body Components. In: Procedia Engineering [online]. 2014. vol. 69, pp. 758-767. Available from: DOI 10.1016/j.proeng.2014.03.052.

[4] WANG, W., Meng, L., ZHAO, Y., and WEI, X. Study on stretch bendability and shear fracture of 800MPa dual phase steel sheet. In: Materials \& Design (1980-2015) [online]. 2014, vol. 56, pp. 907-913. Available from: DOI: 10.1016/j.matdes.2013.12.004.

[5] SILVA, C., SILVA, F., GOUVEIA, R. Investigations on the edge crack defect in Dual Phase steel stamping process. In: Procedia Manufacturing [online]. 2018, vol. 17, pp. 737-745. Available from: DOI: 10.1016/j.promfg.2018.10.124.

[6] KIM, S.B., HUH, H., BOK, H.H., and MOON, M.B.. Forming limit diagram of auto-body steel sheets for high-speed sheet metal forming. In: Journal of Materials Processing Technology [online]. 2011, vol. 211(5), pp. 851-862. Available from: DOI: 10.1016/j.jmatprotec.2010.01.006.

[7] KUZIAK, R., KAWALLA, R. and WAENGLER, S. Advanced high strength steels for automotive industry. In: Archives of Civil and Mechanical Engineering [online]. 2008, vol. 8(2), pp. 103-117. Available from: DOI: 10.1016/S1644-9665(12)60197-6.

[8] KONG, Z., ZHANG, J., LI, H. and KONG, N. Deep drawing and bulging forming limit of dual-phase steel under different mechanical properties. In: The International Journal of Advanced Manufacturing Technology [online]. 2018, vol. 97(5-8), pp. 2111-2124. Available from: DOI: 10.1007/s00170-018-1980-3.

[9] VALEŠ, M., PAČÁK, T. and TATÍČEK, F. Feasibility Study of Manufacturing Outer Car Body Parts with Use of DP500. In METAL 2017: 26th International Conference on Metallurgy and Materials. Ostrava: TANGER, 2017, pp. 561-566.

[10] YAN, B., LAURIN, K., XU, K., SRIRAM, S., HUANG, M., CHINTAMANI, J., and LALAM, SH. A New Dual Phase Steel for Automotive Body Panels [online]. 2003. vol. 3. Available from: DOI: 10.4271/2003-01-0518.

[11] GOMES, T., SILVA, F.J.G., and CAMPILHO, R.D.G.S. Reducing the Simulation Cost on Dual-phase Steel Stamping Process. In: Procedia Manufacturing [online]. 2017, vol. 11, pp. 474-481. Available from: DOI: 10.1016/j.promfg.2017.07.138.

[12] INGARAO, G., Di LORENZO, R., MICARI, F. Analysis of stamping performances of dual phase steels: A multi-objective approach to reduce springback and thinning failure. In: Materials \& Design [online]. 2009, vol. 30, no. 10, pp. 4421-4433. Available from: DOI: 10.1016/j.matdes.2009.04.001. 